\title{
EFFECT OF CHEMICAL AND BIO-FERTILIZERS ON THE GROWTH AND ACTIVE INGREDIENTS OF MAJORANA HORTENSIS PLANT
}

Kandeel, A. M. ${ }^{(1)}$; Sharaf, M. S. ${ }^{(1)}$; Ibrahim, S. G. ${ }^{(2)}$ and Abdallah, Nawal, $H$.

1) Faculty of Agriculture, Ain Shams University 2) AgricultureResearch Center (ARC)

\begin{abstract}
The experiment was carried out in the experimental farm of ElKanaterResearch Station, Horticulture Research Institute, Kalubia Governorate, Egypt. Cultivation of seedling carried out in two seasons 20112012/2012-2013to study the effect ofN.P.K. fertilizers and boifertilizer on Majorana Plant. This work was designed in order to investigate the possibility of reducing the need for NPK chemical fertilization as well as improving plant productivity by using bacterial biofertilization as an alternative. The plants of control treatment received only the full recommended rate of NPK chemical fertilization as ammonium sulphate, calcium superphosphate and potassium sulphate. For the other treatments, a single inoculum or mixture of different inoculum combinations of Azotobacterchroococcum and Azospirillumlipoferum were used in combination with NPK chemical fertilizer as quarter or half dose of the full recommended rate. The experiment was complete random parts to study the effect of nitrogen fixing bacteria application (Azospirillumlipoferum and Azotobacterchroococcum).

The results revealed that the application of biological fertilizers plays a remarkable role in improving yield quality and quantity in Marjoram and can be viewed as a suitable replacement for chemical fertilizers.
\end{abstract}

Keywords: Chemical fertilization, Bio-fertilization, Majoranahortensis 
J. Environ. Sci.

Institute of Environmental Studies and Research - Ain Shams University

\section{INTRODUCTION}

Recently, medicinal and aromatic plants play a major role in agriculture and industry. They are validating drug safety as raw substances used in manufacturing of pharmaceuticals. Some of their components are the nucleus to the chemical biosynthesis for some important drugs such as cortisone, sex hormones, plasma substitute and others. Also, aromatic plants are used in manufacturing of cosmetics, beverages, flavoring agent, etc.

It is very important to produce chemical free, environment friendly medicinal and aromatic herbs for drugs extraction as well as medicines and cosmetics manufacturing as a main substance for human disease healing and health care. Inorganic fertilizers applied to agricultural crops have a great beneficial potential to maximize yields, that can contribute also to environmental pollution (air, water, soil), when applied in too high quantities, at the wrong time or within inappropriate application techniques. Increasing use of fertilizers in agriculture deteriorate environment and cause harmful impacts on living beings due to insufficient uptake of these fertilizers by plants results, fertilizers reaches into water surfaces causes eutrophication in water subsurface and affect living beings including growth inhabiting microorganism. The excess use of chemical fertilizers in agriculture are costly and also have various adverse effects on soils, i.e. depletes water holding capacity, soil fertility and disparity in soil nutrients. The optimal amount and modern management practice guaranty high yield and quality products and minimize possible negative effects. It was felt from a long time to develop 
some low cost effective and eco-friendly fertilizers which work without disturbing nature (Deepali and Gangwar, 2010).

Biofertilizers are very important to produce medicinal and aromatic plants for drugs extraction and manufacturing as a main substance for human disease healing and health care. Producing such drugs has to be clean, having no or the least chemical residues of any harmful kinds. Additionally, biofertilizers are substitution of chemical fertilizers for healthy and cheap production (SubbaRao, 1981). The effect of biofertilization on the growth and productivity of medicinal plants was applied by Hassan et al. (2010) on khella; Hassan (2009) on roselle; Harbet al. (2011) on black cumin using chemical fertilizers combined with biofertilzers resulted in higher values of volatile oil yield/plant and per fed.

The plant chosen in this investigation is marjoram Majoranahortensis, L. Fam. Lamiaceae (mint family). Marjoram is a popular herb from Europe. It is indigenous to Mediterranean countries and was known to the ancient Egyptians, Greeks and Romans (Tainter and Grenis. 1993).

Majoranahortensis is cultivated as culinary herbs and garden plants as well it is valued as a medicinal plant for improving antiseptic, antispasmodic, carminative, stimulant, and expectorant and nerve tonic rheumatic habits, stimulates. Moreover, the blood circulation, nerve, muscle pain, muscle rheumatism arthritis, flu, cold, bronchitis, stucked cough, asthma, hiccups, slow digestion, bad appetite, menstruation problems, blood pressure, worm infections, cramps, mould infections (El-Ghorabet al., 2004). Essential oil is very strong and very pleasant fragrance, the highest essential oil percentage is found in the leaves, whereas only traces are found in flowers and stalks 
(Guenther, 1974). Major components of the volatile oil are monoterpenoids; a-pinenebetapinene, sabinene, myrcene, a-terpinene, y-terpinene, paracymene, terinolene, a-phellandrene, betaphellandrene. Sesquiterpenoids: beta-caryphyllene, a-humulene. Monoterpenols: linalool, terpine-1-ol-4, terpine-1-ol-3, a-terpineol, cisthuyanol-4, trans-thuyanol-4. Terpenic esters: linalyl-acetate $0.1-3 \%$ terpenyl-acetate ,geranyl-acetate,phenolmethyl-ethers; trans-anethol(Kumar et al., 2011).

The objective of the study was the judicious of NPK chemical fertilization by investigating the effect of inoculation with bacterial cultures of nitrogen fixing bacteria Azospirillumlipoferum and Azotobacterchroococcum as biofertilization, alone or combined, plus full, half or quarter dose of chemical NPK fertilizers on vegetative growth, active constituents and chemical composition of marjoram (Majoranahortensis, L.) plants.

\section{MATERIALS AND METHODS}

Location of experiment: This study was carried out at the experimental field of theHorticulture Research Station at Al Qanater-Al Khairya, Agriculture Research Center (ARC), for two successive seasons (2011/2012 and 2012/2013).To study the effect of mineral and biological fertilization on the growth and active ingredients of Majoranahortensis plant.

Bacteria used: Active strains of Azotobacterchroococcum and Azospirillumlipoferum were provided from Unit of Biofertilizers, Faculty of Agriculture, Ain Shams Univ., Shoubra El-Kheima, Egypt. 
Seeds and soil: The marjoram seeds were kindly provided from theHorticulture Research Station at Al Qanater-Al Khairya, Agriculture Research Center (ARC)(Barely Island Farm)Farmer Gezera Al-Shaeer

Table (1): Physical and chemical analysis of the soil used for growing marjoram plant.

\begin{tabular}{|c|c|c|c|}
\hline \multirow{4}{*}{ Physical analysis } & \multicolumn{2}{|l|}{ Sand $\%$} & 55.2 \\
\hline & \multicolumn{2}{|l|}{ Silt \% } & 26.3 \\
\hline & \multicolumn{2}{|l|}{ Clay \% } & 18.5 \\
\hline & \multicolumn{2}{|c|}{ Soil texture } & Sandy loam \\
\hline \multirow{10}{*}{ Chemical analysis } & \multicolumn{2}{|c|}{ Electrical conductivity $\left(\mathrm{dSm}^{-1}\right)$} & 2.10 \\
\hline & \multicolumn{2}{|c|}{$\mathrm{pH}$} & 7.5 \\
\hline & \multirow{4}{*}{ Soluble anions (meq/L) } & $\mathrm{CO}_{3}{ }^{--}$ & $\ldots \ldots$ \\
\hline & & $\mathrm{HCO}_{3}^{-}$ & 3.75 \\
\hline & & $\mathrm{Cl}^{-}$ & 6.5 \\
\hline & & $\mathrm{SO}_{4}^{--}$ & 15.05 \\
\hline & \multirow{4}{*}{ Soluble cations $(\mathrm{meq} / \mathrm{L})$} & $\mathrm{Ca}^{++}$ & 14.4 \\
\hline & & $\mathrm{Mg}^{++}$ & 5.3 \\
\hline & & $\mathrm{Na}^{+}$ & 4.25 \\
\hline & & $\mathrm{K}^{+}$ & 1.35 \\
\hline
\end{tabular}

Experimental procedure: Seeds of Majoranahortensis plants had been sown in outdoor nursery beds with a sandy soil.

Ammonium nitrate $(33.5 \% \mathrm{~N})$, calcium superphosphate $\left(15.5 \% \mathrm{P}_{2} \mathrm{O}_{5}\right)$ and potassium sulphate $\left(48 \% \mathrm{~K}_{2} \mathrm{O}\right)$ were used for NPK fertilization, respectively. The inorganic were used at two rates:

1- Full of the recommended field rate, i.e. 300, 200 and $100 \mathrm{~kg} / \mathrm{fed}$. Ammonium nitrate, calcium superphosphate and potassium sulphate equal $\left(100,31\right.$ and $48 \mathrm{~kg} /$ fed.) of $\mathrm{N}, \mathrm{P}_{2} \mathrm{O}_{5}, \mathrm{~K}_{2} \mathrm{O}$ respectively (as a control). 
2- Half of the recommended field rate, i.e. 150,100 and $50 \mathrm{~kg} /$ fed. equal (50, 15.5 and $24 \mathrm{~kg} /$ fed.) of $\mathrm{N}, \mathrm{P}_{2} \mathrm{O}_{5}, \mathrm{~K}_{2} \mathrm{O}$ respectively.

3- Quarter of the recommended dose, i.e. 75,50 and $25 \mathrm{~kg} / \mathrm{fed}$. equal (25, 7.75 and $17 \mathrm{~kg} /$ fed.) of $\mathrm{N}, \mathrm{P}_{2} \mathrm{O}_{5}, \mathrm{~K}_{2} \mathrm{O}$ respectively.

Calcium superphosphate was added during soil preparation, while $\mathrm{N}$ and $\mathrm{K}$ were added into 3 equal doses as follows:
a)- 30 days after transplantation.
b)- 2 weeks after the first harvest.
c)- 2 weeks after the second harvest.

After 45 days, marjoram seedlings were transplanted in $30 \mathrm{~cm}$ diameter plastic bags filled with $6 \mathrm{~kg}$ of clay soil (obtained from Al Qanater Research Station).

The plants received the following fertilization treatments

$\mathrm{T}_{1}$-Uninoculated(Control) + full dose of NPK.

$\mathrm{T}_{2}$-Azotobacterchroococcum.

$\mathrm{T}_{3}$ - Azospirillumlipoferum.

$\mathrm{T}_{4}$ - Azotobacterchroococcum + Azospirillumlipoferum

$\mathrm{T}_{5}$ - Azotobacterchroococcum $+25 \% \mathrm{NPK}$

$\mathrm{T}_{6}-$ Azotobacterchroococcum $+50 \%$ NPK

$\mathrm{T}_{7}$-Azospirillumlipoferum $+25 \% \mathrm{NPK}$

$\mathrm{T}_{8}$-Azospirillumlipoferum $+50 \%$ NPK

$\mathrm{T}_{9}$ - Azotobacterchroococcum + Azospirillumlipoferum $+25 \%$ NPK

$\mathrm{T}_{10}$ - Azotobacterchroococcum + Azospirillumlipoferum $+50 \%$ NPK 
Inoculation was carried out by immersing the seedlings roots in cell suspension of either Azotobacterchroococcum or Azospirillumlipoferum (contained about $10^{8}$ cells $/ \mathrm{ml}$ ) or their mixture for 30 minutes.

Layout of the experiment: The experiment was designed using the randomized complete blocks design. The experiment included 10 treatmentswith3 replicates, each consisting of 5 pots (bags) treatment.

Data recorded: The plants were harvested in 3 separated cuts / season (first week of May,first week of August and first week of November for both seasons) by cutting the vegetative parts of all the plants $5 \mathrm{~cm}$ above the soil surface .

Thefollowing measurements were recorded at each cut:

\section{1- Vegetative growth parameters}

- Plant height (cm).

- Number of branches /plant.

- Herb fresh weight (g/plant)

- Herb dry weight (g/plant)

The herb was dried at $70{ }^{\circ} \mathrm{C}$ until a constant weight was obtained, then the herb dry weight was recorded.

\section{2- Essential oil}

a)- Essential oil content (\% of fresh weight) in the herb: The oil percentage was determined according to the British pharmacopeia (1963). Satisfactory results were obtained by distillation of $50 \mathrm{gm}$ of fresh herb for 2.5-3.0 hours. The herb was placed in a flask of $1000 \mathrm{ml}$ capacity. An amount of water, weighing about 4-5 times as much as the plant material, was added. Aproper essential oil trap and condenser were attached to the flask and 
enough water was added to fill the trap. The flask was placed on an electrically heated bath. The distillation continued for $2.5-3.0$ hours until no further increase in the oil was observed. The oil was permitted to stand undisturbed so that a good separation from water could be obtained .

b)-Essential oil components: Samples taken from the oil obtained in the second cut of each season were analyzed using gas liquid chromatographically analysis, to determine their main constituents. The use of GLC in the quantitative determinations was performed using the methods described by Bunzenet al.(1969) and Hoftman (1967),which are based on peak area measurements. Briefly $0.3 \mathrm{ml}$ of the volatile oil was dissolved in $10 \mathrm{ml}$ diethyl ether and $1 \mu \mathrm{l}$ was injected into a gas chromatograph (Hewlett Packard, 5890 Series 11) equipped with fused silica capillary column with a coating film of HP-20M carbowax $(0.32 \mathrm{~mm}$ i.i and $25 \mathrm{~m}$ long ). Nitrogen flow rate at $30 \mathrm{ml} / \mathrm{min}$, hydrogen flow rate of $30 \mathrm{ml} / \mathrm{min}$, and air flow rate of $300 \mathrm{ml} \mathrm{min} \mathrm{with} \mathrm{an} \mathrm{initial} \mathrm{temperature} \mathrm{of}$ $40{ }^{\circ} \mathrm{C}$ min final temperature of $120^{\circ} \mathrm{C}$ for $2 \mathrm{~min}$, injection temperature of $150{ }^{\circ} \mathrm{C}$ and the flame ionization detector temperature was $170{ }^{\circ} \mathrm{C}$, Chart speed was $120 \mathrm{sec} \mathrm{cm}$ Rang 32; The reference (authentic) materials were injected with the samples to be analyzed and the authentic samples were compared for the identification of the components of the oil from different treatments. 
The area of each peak was first calculated by an automatic integrator. The areas were then summed. The total area of the peaks represented the whole sample. The percentage of each component was the ratio between its peak areas to the total peak area, multiplied by 100 .

Statistical analysis of data: Data recorded on growth oil content and oil yield were statistically analyzed, and separation of means was performed using the Duncan test at the 5\% level as described by Little and Hills (1978).

\section{RESULTS AND DISCUSSION}

\section{Effect of differentmineral and bio-fertilizers treatments on plant height:}

Data presented in Table (1) show that control plants were shorter in height than other treatments. Utilization of mix of Azospirillumlipoferum and Azotobacterchroococcumincombination with $50 \%$ of recommended NPK dose (T10) gave the tallest plant at first cut in both years. Moreover, second and third cuts showed decline in plant heights compared to first cut. Azospirillumlipoferum or combination of both strains showed significant increase in plant height. The maximum significant increase of plant height was $63.7 \mathrm{~cm}$ at the first cut of T10 treatment .T10 and T3 showed the tallest plant in the first and second cut respectively of 2011. However, third cut height under both strains in combination application in T8, T9, T10 gave the taller plants 40.7, 40.3 and 39.3 respectively. T4 and T10 gave tallest plant 49.3 and $52.0 \mathrm{~cm}$ at first cut of 2013 .

However, in second and third cuts plants were shorter than first cut third cut showed similarity among treatments except control. 
Azotobacter is able to produce antifungal compounds that fight plant diseases and improve viability and germination of the plantlets and, as a result, improve the overall plant growth (Chen, 2006).

Table (1): Effect of different mineral and bio-fertilization treatments on plant height at different cuts of Majoranahortensis.

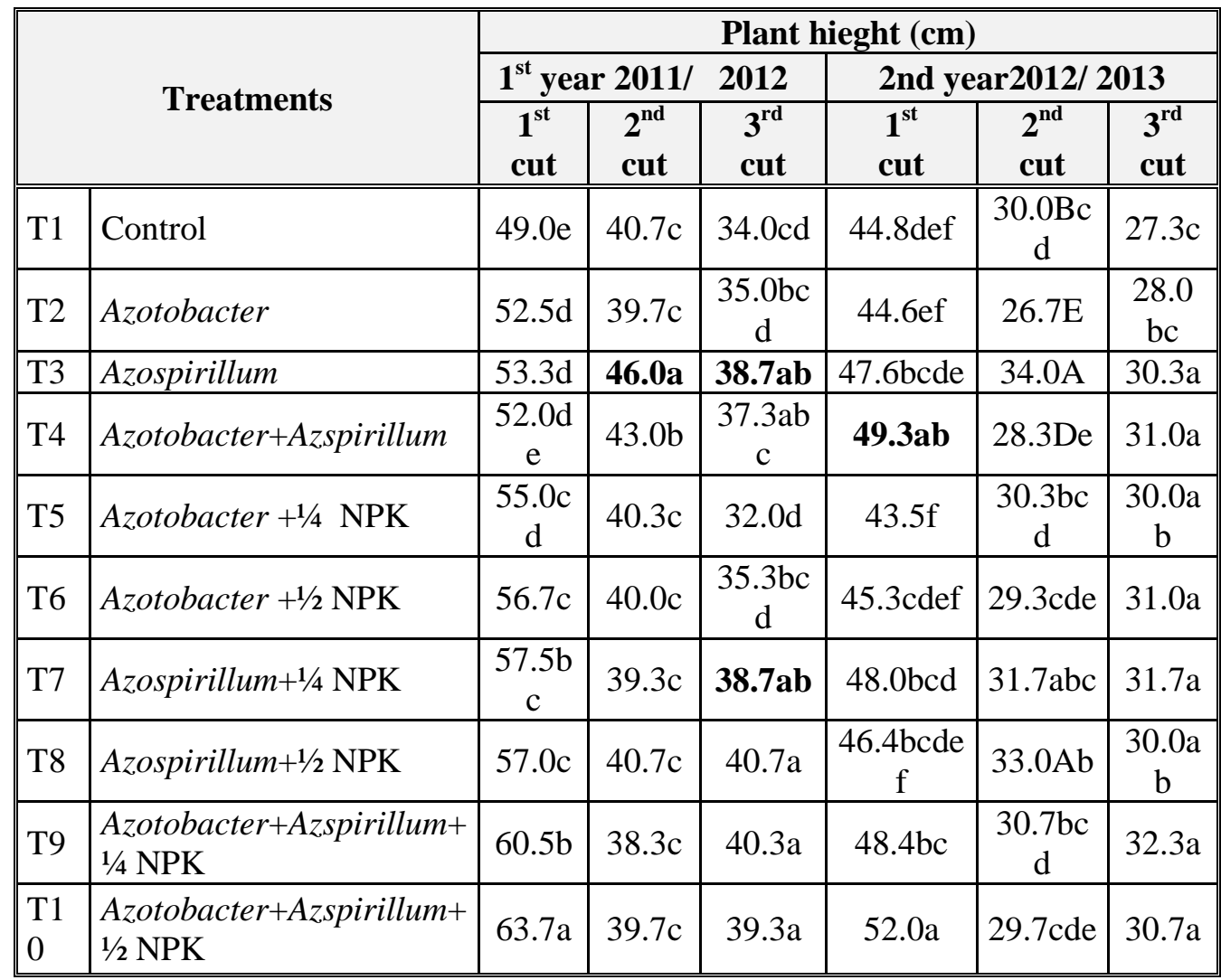

$\mathrm{N}=$ nitrogen, $\mathrm{P}=$ phosphours, $\mathrm{K}=$ potassium, $1 / 4=25 \% / 1 / 2=50 \%$

Means with the same letter are not significantly different. 


\section{Effect of differentmineral and bio-fertilizers treatments on fresh weight:}

Data presented in Table (2) show that fresh weights were positive increment in the second cut compared to with the first and reduction was observed in the third one. Alteration of mineral fertilization with biofertilizer showed significant advances in cultivation of Majoranahortensis. Fresh weight showed variability among treatments in both growing seasons and different cuts.

In both years and all cuts treatments showed significant difference than control. In which, reducing amount of $\mathrm{N}, \mathrm{P}, \mathrm{K}$ and use single or combined strains of Azospirillumlipoferum and Azotobacterchroococcum gave better result than control.

Reduction synthetic fertilizer to one quarter or half gives better results than non-fertilized control or odd use of biofertilizer. Azotobacterchroococcum with reduced amount of chemical fertilizer gives better results than Azospirillumlipoferum or in combination together. Overall difference between using Azotobacterchroococcum combined with synthetic fertilizer gave $10-55 \%$ than control and showing better tendency by $10 \%$ than use of Azospirillumlipoferum. However, use of both strains combined did not improve plant fresh weight.T6 has increased fresh weigh significant in all cuts of first year of 2011. T6 and T7 showed the fresh weight in the first cut 46.6 and 48.2 respectively. However, T9 treatments includeboth strains of biofertilizer showed significant increase in the second cutof 2013 in second year. 
T7 demonstrated significant affect on fresh weight of third cut in the first year gives better perform. First and second cutsgave better fresh weight in 2013 compared for what obtained in the first year.

However, second and third cut of the first year showed similar fresh weight over all fresh weight was higher in the first year compared to second year.

Biofertilizers are microbial inoculates used for application to either seed or soil for increasing soil fertility with the objective of increasing the number of such microorganisms and to accelerate certain microbial processes in the rhizosphere of inoculated plants or soil. Such microbiological processes can change unavailable forms of nutrients into available ones that can be easily assimilated by plants, and then increased herb fresh weight of marjoram (SubbaRao, 1993). 
Table (2): Effect of different mineral and bio-fertilization treatments on fresh weight at different cuts of Majoranahortensis.

\begin{tabular}{|c|c|c|c|c|c|c|c|c|c|}
\hline \multirow{3}{*}{\multicolumn{2}{|c|}{ Treatments }} & \multicolumn{6}{|c|}{ Fresh weight (g/plant) } & \multirow{2}{*}{\multicolumn{2}{|c|}{$\begin{array}{c}\text { Total } \\
\text { production } \\
\text { of fresh herb }\end{array}$}} \\
\hline & & \multicolumn{3}{|c|}{$1^{\text {st }}$ year $2011 / 2012$} & \multicolumn{3}{|c|}{ 2nd year2012/2013 } & & \\
\hline & & $1^{\text {st }}$ cut & $2^{\text {nd }}$ cut & $3^{\text {rd }}$ cut & $1^{\text {st }}$ cut & $2^{\text {nd }}$ cut & $3^{\text {rd }}$ cut & $1^{\text {st }}$ year & $\begin{array}{l}\text { 2nd } \\
\text { year }\end{array}$ \\
\hline T1 & Control & 31.0E & $60.5 \mathrm{~cd}$ & $54.0 F$ & 34.4e & $64.2 \mathrm{e}$ & $32.2 \mathrm{~F}$ & $145.5 \mathrm{e}$ & $130.8 \mathrm{e}$ \\
\hline $\mathbf{T 2}$ & Azotobacter & 34.7D & $59.3 d$ & 56.0Ef & 41.8d & $72.1 \mathrm{~cd}$ & 36.0ef & $150.0 d$ & 149.9d \\
\hline T3 & Azospirillum & $39.4 \mathrm{C}$ & 66.3ab & 61.7Bcd & $42.3 \mathrm{~cd}$ & 75.2c & $41.4 \mathrm{~cd}$ & $167.4 \mathrm{c}$ & $158.9 \mathrm{~cd}$ \\
\hline T4 & Azotobacter + Azspirillum & $40.7 \mathrm{Bc}$ & $59.3 d$ & 64.3Abc & $44.4 \mathrm{~cd}$ & $74.1 \mathrm{~cd}$ & 45.7Abc & $164.3 \mathrm{bc}$ & $164.2 \mathrm{~cd}$ \\
\hline T5 & Azotobacter $+1 / 4$ NPK & $39.4 \mathrm{C}$ & $58.3 d$ & 60.0Cde & $43.5 \mathrm{~cd}$ & 70.7d & $40.5 \mathrm{de}$ & $157.7 \mathrm{c}$ & $154.7 \mathrm{~cd}$ \\
\hline T6 & Azotobacter $+1 / 2$ NPK & $46.6 \mathrm{~A}$ & $68.3 \mathrm{a}$ & $68.0 \mathrm{~A}$ & $46.9 b$ & $75.3 \mathrm{c}$ & $50.2 A$ & $182.9 a$ & 172.4a \\
\hline T7 & Azospirillum $+1 / 4$ NPK & $48.2 A$ & $66.7 \mathrm{ab}$ & 63.3Bc & 49.5a & $72.5 \mathrm{~cd}$ & 46.4ab & 178.2a & $168.4 b$ \\
\hline T8 & Azospirillum $+1 / 2$ NPK & $38.7 \mathrm{C}$ & $68.3 \mathrm{a}$ & 57.3def & 42.0d & 86.6a & 37.9de & $164.3 \mathrm{c}$ & $166.5 d$ \\
\hline T9 & $\begin{array}{l}\text { Azotobacter }+ \text { Azspirillum }+1 / 4 \\
\text { NPK }\end{array}$ & $39.8 \mathrm{C}$ & $60.7 \mathrm{~cd}$ & 64.0abc & 43.8cd & 79.3b & $41.3 \mathrm{~cd}$ & $164.5 \mathrm{c}$ & $164.4 c d$ \\
\hline T10 & $\begin{array}{l}\text { Azotobacter }+ \text { Azspirillum }+1 / 2 \\
\text { NPK }\end{array}$ & 42.9B & $63.3 \mathrm{bc}$ & 65.0ab & 44.8bc & 89.9a & 42.7bcd & 171.2b & 177.4a \\
\hline
\end{tabular}

$\mathrm{N}=$ nitrogen, $\mathrm{P}=$ phosphours, $\mathrm{K}=$ potassium, $1 / 4=25 \% / 1 / 2=50 \%$

Means with the same letter are not significantly different.

\section{Effect of differentmineral and bio-fertilizers treatments on dry weight:}

Results recorded in Table (3) reveal that for cut age of dry weight of the first year was higher than second year was third cut and first cut showed the highest \% DW in first and second year respectively.

In first cut of both years non significant differs or slight difference among treatment was observed.

In 2013 use of combined strains gave higher \% of dry matter maybe due to regulation of water absorption compiled to slight application of strains. 
It could be concluded that the increment in plant dry weight may be attributed to the increase in both plant height, number of branches/plant and plant fresh weight. These results agreed with those obtained by Abo- El-Ala (2002), Kandeel and Sharaf (2003), Mahfouz (2003) and Abo- (2008) on marjoram. They reported that,the highest values of plant height, number of branches, herb fresh and dry weights were recorded for the treatment of biofertilizer in comparison to the other treatments (without biofertilizers) plants.

Table(3): Effect of different mineral and bio-fertilization treatments on percentage of dry weight at different cuts of Majoranahortensis.

\begin{tabular}{|c|c|c|c|c|c|c|c|}
\hline \multirow{3}{*}{\multicolumn{2}{|c|}{ Treatments }} & \multicolumn{6}{|c|}{$\%$ of dry weight } \\
\hline & & \multicolumn{3}{|c|}{$1^{\text {st }}$ year $2011 / 2012$} & \multicolumn{3}{|c|}{ 2nd year2012/ 2013} \\
\hline & & $1^{\text {st }}$ cut & $2^{\text {nd }}$ cut & $3^{\text {rd }}$ cut & $1^{\text {st }}$ cut & $2^{\text {nd }}$ cut & $3^{\text {rd }}$ cut \\
\hline T1 & Control & 24.9Ab & $23.8 \mathrm{bc}$ & $27.9 \mathrm{bc}$ & $27.4 a$ & $18.8 d$ & $16.0 \mathrm{e}$ \\
\hline $\mathbf{T} 2$ & Azotobacter & 24.7Ab & 26.6ab & 27.0bcd & 25.3a & $21.0 \mathrm{~cd}$ & 18.0de \\
\hline T3 & Azospirillum & 26.9A & $27.7 \mathbf{a}$ & 30.3ab & $26.3 a$ & $23.6 \mathrm{bc}$ & 18.0de \\
\hline T4 & $\begin{array}{l}\text { Azotobacter } \\
+ \text { Azspirillum }\end{array}$ & 26.1Ab & 25.7abc & 29.7ab & 23.6a & $23.5 \mathrm{bc}$ & $20.0 \mathrm{~cd}$ \\
\hline T5 & Azotobacter $+1 / 4$ NPK & 23.7B & $24.7 \mathrm{bc}$ & $27.1 \mathrm{bcd}$ & 24.0a & 19.9d & $19.3 \mathrm{~cd}$ \\
\hline T6 & Azotobacter +1/2 NPK & 24.7Ab & 26.5ab & $33.4 a$ & 27.0a & 19.9d & 22.0abc \\
\hline T7 & Azospirillum+1/4 NPK & 25.9Ab & $27.5 a$ & $28.5 \mathrm{bc}$ & $26.6 a$ & 19.2d & 20.7bcd \\
\hline T8 & Azospirillum+1/2 NPK & 23.8B & $24.3 \mathrm{bc}$ & $29.3 \mathrm{~b}$ & 25.1a & $23.7 \mathrm{bc}$ & 23.0ab \\
\hline T9 & $\begin{array}{l}\text { Azotobacter } \\
+ \text { Azspirillum }+1 / 4 \text { NPK }\end{array}$ & $25.5 \mathrm{Ab}$ & 25.9ab & $25.3 \mathrm{~cd}$ & 28.0a & 26.8Ab & 24.0a \\
\hline T10 & $\begin{array}{l}\text { Azotobacter } \\
+ \text { Azspirillum }+1 / 2 \text { NPK }\end{array}$ & 26.7A & 23.1c & 23.5d & 26.1a & 27.5A & $24.0 \mathrm{a}$ \\
\hline
\end{tabular}

$\mathrm{N}=$ nitrogen, $\mathrm{P}=$ phosphours, $\mathrm{K}=$ potassium, $1 / 4=25 \%, 1 / 2=50 \%$

Means with the same letter are not significantly different. 


\section{Effect of differentmineral and bio-fertilizers treatments on oil percentage}

Data presented in Table (4) indicate that the use of biofertilizer stimulate accumulation of oil contents than application of synthetic fertilizers. First \& second cut showed the highest accusation of oil in first and second years. However, first cut of the first year showed the highest accumulation among different cuts. T6 showed $0.87 \%$ accumulation, while control treatment gave $0.54 \%$. Moreover T6 showed stable tendency at different cuts in both years, which reveal good synergy between lowdose of NPK andAzotobacterAzospirillumon accumulation of oil.Kandeel and Sharaf (2003) on marjoram plants, stated that, the highest oilpercentage and oil yield/ ha were obtained with plantsinoculated pre-sowing with three bacterial partners(biological fertilizers) and half of the recommended fieldrate of the inorganic N, P and K fertilization. 
J. Environ. Sci.

Institute of Environmental Studies and Research - Ain Shams University

Table(4): Effect of different mineral and bio-fertilization treatments on oil percentage at different cuts of Majoranahortensis.

\begin{tabular}{|c|c|c|c|c|c|c|c|}
\hline & \multirow{3}{*}{ Treatments } & \multicolumn{6}{|c|}{ Oil percentage (\%) } \\
\hline & & \multicolumn{3}{|c|}{$1^{\text {st }}$ year2011/2012 } & \multicolumn{3}{|c|}{ 2nd year2012/2013 } \\
\hline & & $1^{\text {st }}$ cut & $2^{\text {nd }}$ cut & $3^{\text {rd }}$ cut & $1^{\text {st }}$ cut & $2^{\text {nd }}$ cut & $3^{\text {rd }}$ cut \\
\hline T1 & Control & $0.54 \mathrm{f}$ & $0.55 \mathrm{~d}$ & $0.36 \mathrm{a}$ & $0.58 \mathrm{bcd}$ & $0.56 \mathrm{c}$ & $0.36 \mathrm{Bc}$ \\
\hline $\mathrm{T} 2$ & Azotobacter & $0.55 \mathrm{f}$ & $0.56 \mathrm{~d}$ & $0.33 \mathrm{ab}$ & $0.62 \mathrm{ab}$ & $0.53 \mathrm{c}$ & $0.33 \mathrm{Cdef}$ \\
\hline $\mathrm{T} 3$ & Azospirillum & $0.63 \mathrm{e}$ & $0.63 \mathrm{c}$ & $0.34 \mathrm{ab}$ & $0.51 \mathrm{e}$ & $0.66 \mathrm{~b}$ & $0.34 \mathrm{cde}$ \\
\hline $\mathrm{T} 4$ & $\begin{array}{l}\text { Azotobacter } \\
+ \text { Azspirillum }\end{array}$ & $0.67 \mathrm{de}$ & $0.64 \mathrm{c}$ & $0.31 b$ & $0.56 \mathrm{~cd}$ & $0.68 b$ & $0.31 \mathrm{Ef}$ \\
\hline T5 & $\begin{array}{l}\text { Azotobacter }+1 / 4 \\
\text { NPK }\end{array}$ & $0.78 b$ & $0.72 \mathrm{ab}$ & $0.33 \mathrm{ab}$ & $0.56 \mathrm{~cd}$ & $0.75 \mathrm{a}$ & $0.31 \mathrm{def}$ \\
\hline T6 & $\begin{array}{l}\text { Azotobacter }+1 / 2 \\
\text { NPK }\end{array}$ & $0.87 \mathrm{a}$ & $0.75 a$ & $0.36 \mathrm{a}$ & $0.62 \mathrm{ab}$ & $0.77 \mathrm{a}$ & $0.39 \mathrm{Ab}$ \\
\hline $\mathrm{T} 7$ & $\begin{array}{l}\text { Azospirillum+1/4 } \\
\text { NPK }\end{array}$ & $0.74 b c$ & $0.68 b c$ & $0.35 \mathrm{a}$ & $0.61 \mathrm{ab}$ & $0.74 \mathrm{a}$ & $0.34 \mathrm{cde}$ \\
\hline $\mathrm{T} 8$ & $\begin{array}{l}\text { Azospirillum }+1 / 2 \\
\text { NPK }\end{array}$ & $0.64 \mathrm{e}$ & $0.64 c$ & $0.34 \mathrm{a}$ & $0.55 \mathrm{~d}$ & $0.65 b$ & $0.35 \mathrm{Cd}$ \\
\hline T9 & $\begin{array}{l}\text { Azotobacter } \\
+ \text { Azspirillum }+1 / 4 \\
\text { NPK }\end{array}$ & $0.66 \mathrm{de}$ & $0.66 c$ & $0.36 \mathrm{a}$ & $0.64 \mathrm{a}$ & $0.66 \mathrm{~b}$ & $0.41 \mathrm{~A}$ \\
\hline $\mathrm{T} 10$ & \begin{tabular}{|l|} 
Azotobacter \\
+ Azspirillum $+1 / 2$ \\
NPK
\end{tabular} & $0.71 \mathrm{~cd}$ & $0.64 \mathrm{c}$ & $0.31 b$ & $0.60 \mathrm{abc}$ & $0.65 b$ & $0.30 \mathrm{~F}$ \\
\hline
\end{tabular}

$\mathrm{N}=$ nitrogen, $\mathrm{P}=$ phosphours, $\mathrm{K}=$ potassium, $1 / 4=25 \%, 1 / 2=50 \%$

Means with the same letter are not significantly different

Data presented in Table (4) show that N, P and $\mathrm{K}$ percentages in marjoram plant herb were considerably influenced by the inoculation with A.chroococcum and Azospirillumlipoferum or their mixture combined with NPK fertilizers. Gad (2001) reported that nitrogen, phosphorus, and potassium in leaves of Foeniculumvulgare and Anethumgraveolenswere increased by applying biofertilizers. 
Table (5): Effect of differentmineral and bio-fertilization treatments on percentage of total nitrogen, total phosphorus, total potassium, $\mathrm{CHl}$ (A), $\mathrm{CHl}$ (B) and carotenoids in $3^{\text {rd }}$ cut from Magoranahortensisin season 2012/2013.

\begin{tabular}{|c|c|c|c|c|c|c|c|}
\hline Treatments & $\mathbf{N \%}$ & $\mathbf{P \%}$ & $\mathbf{K} \%$ & CH1(A) & CH1(B) & Carotenoids & Total.Ch \\
\hline $\mathrm{T} 1$ & $1.840 \mathrm{AB}$ & $\begin{array}{c}0.2250 \\
\mathrm{~B}\end{array}$ & $\begin{array}{l}1.250 \\
\mathrm{ABC}\end{array}$ & $0.5300 \mathrm{BC}$ & $0.4400 \mathrm{C}$ & $0.9700 \mathrm{D}$ & $0.8400 \mathrm{D}$ \\
\hline $\mathrm{T} 2$ & $1.370 \mathrm{~B}$ & $\begin{array}{c}0.2390 \\
\text { B }\end{array}$ & $\begin{array}{l}1.000 \\
\mathrm{BCD}\end{array}$ & $\begin{array}{c}0.7400 \\
\mathrm{ABC} \\
\end{array}$ & $0.6400 \mathrm{BC}$ & $1.370 \mathrm{BCD}$ & $0.9200 \mathrm{CD}$ \\
\hline T3 & $1.150 \mathrm{~B}$ & $0.2390 \mathrm{~B}$ & $\begin{array}{c}0.8400 \\
\mathrm{D}\end{array}$ & $\begin{array}{c}0.5800 \\
\mathrm{ABC}\end{array}$ & $0.5000 \mathrm{BC}$ & $0.8600 \mathrm{D}$ & $\begin{array}{l}1.080 \\
\text { BCD }\end{array}$ \\
\hline $\mathrm{T} 4$ & $1.280 \mathrm{~B}$ & $0.3670 \mathrm{~A}$ & $\begin{array}{l}1.040 \\
\text { BCD } \\
\end{array}$ & $0.4400 \mathrm{C}$ & $0.4200 \mathrm{C}$ & $1.010 \mathrm{CD}$ & $0.8600 \mathrm{D}$ \\
\hline T5 & $1.140 \mathrm{~B}$ & $0.2800 \mathrm{~B}$ & $\begin{array}{l}1.000 \\
\mathrm{BCD}\end{array}$ & $\begin{array}{c}0.9100 \\
\mathrm{ABC}\end{array}$ & $0.8300 \mathrm{ABC}$ & $1.730 \mathrm{BC}$ & $\begin{array}{r}1.490 \\
\text { ABCD } \\
\end{array}$ \\
\hline T6 & $1.430 \mathrm{~B}$ & $0.2250 \mathrm{~B}$ & $1.500 \mathrm{~A}$ & $1.160 \mathrm{AB}$ & $0.8100 \mathrm{ABC}$ & $0.9900 \mathrm{D}$ & $\begin{array}{l}1.970 \\
\mathrm{ABC}\end{array}$ \\
\hline $\mathrm{T} 7$ & $2.190 \mathrm{~A}$ & $0.2800 \mathrm{~B}$ & $\begin{array}{c}1.300 \\
\mathrm{AB} \\
\end{array}$ & $1.220 \mathrm{~A}$ & $1.250 \mathrm{~A}$ & $2.560 \mathrm{~A}$ & $2.460 \mathrm{~A}$ \\
\hline T8 & $1.500 \mathrm{AB}$ & $\begin{array}{c}0.2800 \\
\mathrm{~B}\end{array}$ & $\begin{array}{c}0.9600 \\
\mathrm{CD}\end{array}$ & $1.140 \mathrm{AB}$ & $0.9100 \mathrm{AB}$ & $1.850 \mathrm{AB}$ & $2.040 \mathrm{AB}$ \\
\hline T9 & $1.120 \mathrm{~B}$ & $0.300 \mathrm{AB}$ & $\begin{array}{l}1.040 \\
\text { BCD }\end{array}$ & $\begin{array}{l}1.030 \\
\mathrm{ABC} \\
\end{array}$ & $0.8300 \mathrm{ABC}$ & $1.070 \mathrm{CD}$ & $\begin{array}{r}1.860 \\
\text { ABCD } \\
\end{array}$ \\
\hline T10 & $1.290 \mathrm{~B}$ & $\begin{array}{c}0.2570 \\
\text { B }\end{array}$ & $\begin{array}{l}1.000 \\
\text { BCD }\end{array}$ & $\begin{array}{c}0.9500 \\
\mathrm{ABC}\end{array}$ & $0.6600 \mathrm{BC}$ & $1.370 \mathrm{BCD}$ & $\begin{array}{r}1.610 \\
\text { ABCD }\end{array}$ \\
\hline \multirow[t]{2}{*}{ LSD } & 0.7624 & 0.07741 & 0.3192 & 0.6500 & 0.4413 & 0.7303 & 1.050 \\
\hline & $\begin{array}{c}\text { at } \\
\text { alpha }=0.05\end{array}$ & $\begin{array}{c}\text { at } \\
\text { alpha }= \\
0.05\end{array}$ & $\begin{array}{c}\text { At } \\
\text { alpha= } \\
0.05\end{array}$ & 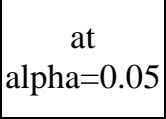 & $\begin{array}{c}\text { at } \\
\text { alpha }=0.05\end{array}$ & $\begin{array}{c}\text { at } \\
\text { alpha }=0.05\end{array}$ & $\begin{array}{c}\text { at } \\
\text { alpha }=0.05\end{array}$ \\
\hline
\end{tabular}

$\mathrm{N}=$ nitrogen, $\mathrm{P}=$ phosphours, $\mathrm{K}=$ potassium, Chlorophyll (A), Chlorophyll (B)

Means with the same letter are not significantly different

Data presented in Table (5) show thatN, $\mathrm{P}$ and $\mathrm{K}$ percentages in marjoram plant herb were considerably influenced by the inoculation with A.chroococcum and Azospirillumlipoferum or their mixture combined with NPK fertilizers.Gad (2001) reported that nitrogen, phosphorus, and potassium 
in leaves of Foeniculumvulgare and Anethumgraveolenswere increased by applying biofertilizers.

\section{REFERENCES}

Abo-El-Ala, H.K. (2002). Biofertilization techniques used forimproving production of some medicinal plants in desert soilPh.D. Thesis, Institute, Environmental, Studies and Res. AinShams Univ., Cairo Egypt.

Abo , M.A.I. (2008). The effect of organic and bio-fertilization sources on the growth and active constituents of MajoranaHortensisL. plant. MSc Thesis, Fac. Agric., Al-Azhar Univ.

Bunzen, J.N., J. Guichard, P. Labble, J. Prevot and J. Trenchant, 1969.Partical Manual of Gas Chromatography. J. Trenchant Ed. El. Seiviet. Publ. Comp. Amst. London pp. 38-44.

British pharmacopeia (1963). Great Britain, General Medical Council, Publisher, Pharmaceutical Press,

Chen, J. (2006). The combined use of chemical and organic fertilizers and or biofertilizer for crop growth and soil fertility.International workshop on sustained management of the soil-rhizosphere system for efficient crop production and fertilizer use, Thailand, pp 16-26.

Deepali, Gangwar, K. K. (2010). Biofertilizers: An ecofriendly way to replace chemical fertilizers.

Http://www.krishisewa.com/cms/articles/2010/biofert.html.

El-Ghorab, A.H.; A.F. Mansour and K.F. El-Massry (2004).Effect of extraction methods on the chemical composition and antioxidant activity of Egyptain marjoram (MajoranahortensisMoench).Flavour Frag. J., 19: 54-61.

Gad, W.M. (2001). Physiological studies on FoeniculumvulgareMill. andAnethumgraveolensL. M.Sc. Thesis. FacultyAgric., Kafr ElSheikh, Tanta Univ., Egypt. 
Guenther, E. (1974). The essential oil of the plant familiesrutaceae and Labiateae. R.E. Krieger Publishing, Florida,. (3): 156 p.

Harb, E.M.Z.; A.M. Ghallab and S.H.D. Soliman, (2011).Effect of mycorrhizae, Azotobacter and organic manure on the growth, seed yield and oil content of Nigella sativa L. plants grown under two levels of chemical fertilizers, NPK. Bull. Fac. Agric. Cairo Univ., 62: 173-182.

Hassan, F.A.S., (2009). Response of Hibiscus sabdariffaL. plant to some biofertilization treatments. Ann. Agric. Sci., Ain Shams Uni., 54:437-446.

Hassan, E. A., E.A. Hassan and E.H. Hamad, (2010).Microbial solubilization of phosphate-potassium rocks and their effect on khella (Ammivisnaga) growth. Ann. Agric. Sci., 55: 37-53.

James, E.K. (2000).Nitrogen fixation in endophytic and associative symbiosis. Field Crop Res., 65, 197-209.

Kandeel, A. M. and M. S.Sharaf (2003). Productivity of Majoranahortensis, L.plants as influenced by the interactions between mineral andbiological fertilization. J. Agric., Sci., Mansoura Univ., 28(2): 1373-1389.

Kumar, B.V.N.S.; M.R. Kumar; T. Tamizhmani; O.M.F. Rahiman and K.M. Niyas (2011).Majoranahortensis (M.): A review update. PharmaSeince Monitor. International Journal of Parmaceutical Sciences, 2:59-74.

Little, T. M. and F. J. Hills. (1978). Agricultural Experimentation: Design and Analysis. Publisher, Wiley41-98.

Mahfouz, S.A. (2003). Effect of biofertilization on growth and oilproduction of marjoram (MajoranahortensisL.). Ph. D. Thesis, Fac.Agric. Cairo Univ, Egypt.

SubbaRao, N. S. (1981). Biofertilizers in Agriculture. Oxford and IBH Publishing Co., New Delhi, Bombay, Calcutta, pp: 69, 77-92, 142-160.

SubbaRao, N.S. (1993).Biofertilizers in Agriculture and Forestry, Oxford \& IBM publishing Co., Ltd. $3^{\text {rd }}$ edition24-58. 
Tainter, D.R. and A.T. Grenis (1993). Spices and Seasonings: A food technology hand book. VCH Publishers Inc., New York25-38.

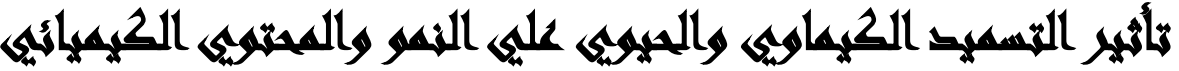

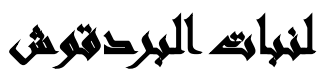

\section{[०]}

عواض محمد قنديل(')- محمد سيد السيد شرف(')- سعيد جبر إبراهيم(؟)- نوال حسن عبد الله () كلية الزراعة جامعة عين شمس ؟) معهد بحوث البساتين، مركز البحوث الزراعية بالدئ.

\section{(ll}

أجريت هذه التجربة فى مزرعة جزيرة الثعير فى مركز البحوث الزراعية بالقناطر الخيرية

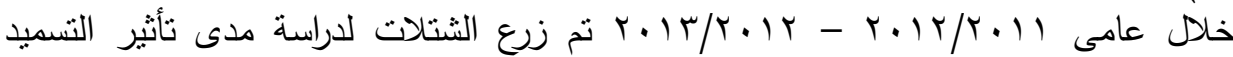

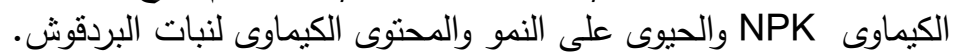

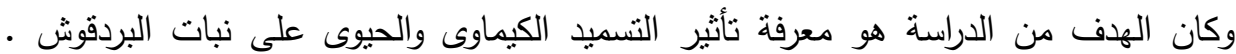

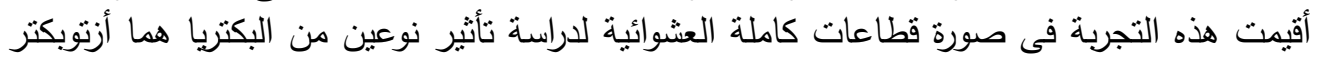

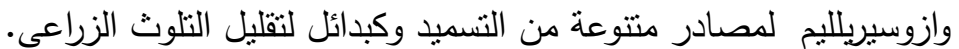

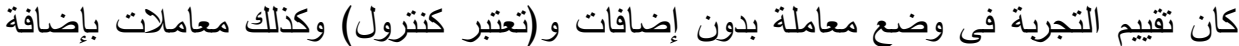

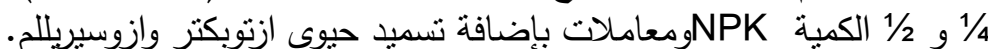

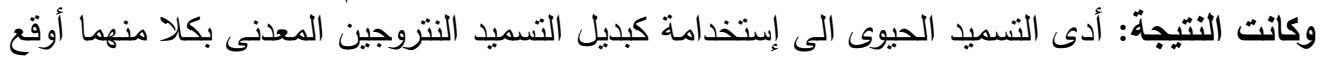
وجود خليط منهما إلى تحسين كمية العشب الاخضر وكذانلك نسبة المباد المواد الفعالة وخفض نسبة النترات والنتريت مما يسمح باستهلالك البردقوش دون مشاكل صحية. 